\title{
PRE-SERVICE TEACHERS' TRAINING FOR THE INNOVATIVE EXTRACURRICULAR WORK
}

\author{
Nataliia Onyshchenko, Nataliia Serdiuk, Valentyna Krykun
}

\author{
Hryhorii Skovoroda University in Pereiaslav, \\ Pereiaslav, Ukraine \\ onischenkon@gmail.com
}

\begin{abstract}
The research proves that the level of pre-service teachers' readiness for innovative extracurricular work at school will be increased together with the general index of their satisfaction with the extracurricular work at university after the implementing the designed holistic programme of their training. The participants of the pedagogical experiment were 148 students, divided into experimental and control groups; the experts were 18 teachers of Philological Faculty of the Hryhorii Skovoroda University in Pereiaslav and 10 General Secondary Schools teachers (Pereiaslav, Ukraine). After implementation of the programme, 27\% of participants were ready for innovative extracurricular work at the high level, $62 \%$ of students increased their level of readiness for innovative extracurricular work to the middle one. The suggested programme also increased the students' satisfaction with the extracurricular work at university. On the basis of the research results, the authors suggest methodical recommendations for educators.
\end{abstract}

Keywords: pre-service teacher; university training; innovative extracurricular work; satisfaction; readiness.

\section{Introduction}

In the context of Ukraine entering the European space, the key emphasis of the education content updating should be related to the essence of the student-centred vocational education. This involves training teachers as highly educated, spiritually rich and intellectually mature people. They should be satisfied with the quality of their education, responsible personalities and be capable of not only being able to reveal their own individualities in the future vocational activity but also to manage the school's prosperity, profitability and development. Consequently, this would make the educational process more interesting and innovative. With this in mind, the problem of training pre-service teachers for the innovative extracurricular work during their study at Ukrainian pedagogical university is considered to be greatly beneficial.

The need for a generation of new teachers has recently increased because the situation on the educational services market has changed dramatically and the competitive struggle between higher educational institutions for every student has been intensified. This has increased the role and importance of educational leaders, who must possess a wide range of professional qualities and be ready to lead a team, to self-manage and to care about the results of pedagogical activity. They also have to be aware of the uniqueness of its purpose and at the same time the great complexity of its achievement, along with maintaining the responsibility for its work. There is currently a very high demand for such specialists, and this has been confirmed by the high standards expected from the most sought-after professions in the labour market. It should be noted that despite some expert forecasts that the most requested skills in 2021 job market will be the ability for life long learning, critical and creative thinking, seting goals their achievement, communication in a multicultural environment. Sadly, the Ukrainian higher education system does not always train for these skills to the fullest degree.

Nowadays it is important for higher education institutions to follow the principle of a student-centred environment. This can be made possible by facilitating the formation of individual opportunities within the implementation of pedagogical activities, improving the level of pedagogical skills of pre-service teachers, generally increasing the level of their satisfaction with the quality of education and readiness for innovative extracurricular work. An important element to alleviating this problem involves also considering the foreign and Ukrainian experience, along with various trends and innovations. In this context, the transformation of classical university extracurricular work into the modern innovative one becomes one of the key aspects for increasing the level of pre-service teacher satisfaction with it. So, the realisation of the potential of innovative extracurricular work with students during their studies at the higher pedagogical education institutions of Ukraine is of immediate interest.

The concept of the research is based on understanding the process of forming the pre-service teachers' readiness for innovative extracurricular work as acomponent of their professional training on the ground of

(C) Nataliia Onyshchenko, Nataliia Serdiuk, Valentyna Krykun. 2021. Published by Igor Sikorsky Kyiv Polytechnic Institute. This is an Open Access article distributed under the terms of the licence CC BY 4.0 
involving students in an innovative university educational environment. The fundamentals of pedagogical innovation studies are acquired, and the received knowledge and skills of that extracurricular work are put into practice.

The scientific analysis of the research problem and review of the current state of professional training in educational institutions testifies to the need to resolve a number of contradictions between the traditional preservice teachers' training and the modern school needs; demand for teachers as creative educational managers, ready for future innovative extracurricular work, and the insufficient level of pre-service teachers' readiness for this type of activity; demand to introduce innovations and foreign languages into the training of pre-service teachers of all specialities into educational process at higher education and their absence in extracurricular work; the need to develop new conceptual approaches and methods of pre-service teachers' training for innovative extracurricular activities and the insufficient level of systematic research on this issue.

\section{Literature review}

Different aspects of studying the pre-service teachers' training at higher-educational institutions have been investigated in the works of many scientists. The fundamentals and problems of the development of higher education were studied by Solovey and Demchuk (2017), Serdiuk (2018) etc. The features of innovative higher education were analysed by Hepp et al. (2015), Onyshchenko (2012), Shapran and Shapran (2010). The various aspects of the pre-service teachers' extracurricular activities organization were discussed by Tazhbayeva (2015), Marsh and Kleitman (2002), Pejić-Papak and Vidulin-Orbanić (2011); teaching students within extracurricular activities at university was investigated by Alhasov, Verbytska and Kolenichenko (2020), Sandal, Detsiuk and Kholiavko (2020). The researchers studied the impact of extracurricular activity on teacher job satisfaction (Moran, 2017) and students (George, 2012; Massoni, 2011; Wilson, 2009). But the questions how to train students to be ready for the future extracurricular work at school, how to increase their satisfaction with it during studies at pedagogical universities, how to implement the ideas of innovative extracurricular work with the pre-service teachers within the higher education of Ukraine haven't become the subject of special research and haven't been answered yet.

Considering the fact that innovation is the requirement of time (Wang and Yang, 2009), one of the most important problems of modern education is training pre-service teachers for innovative extracurricular activity at school. We fully agree with the fact that innovative pedagogical technologies intensify the teaching process through implementing active, analytical and communicative ways of learning; form future specialists' professional competence; develop the ability of making the right decisions in unusual situations and skills for creating author's technologies and pre-service teachers' art potential (Onyshchenko, 2012, p.42). The problem of qualitative practical training of a specialist has always existed and attracted the attention of educators. Since its solution is directly related to the issue of the graduate's readiness for practical professional activity, in recent years the concept of "innovative extracurricular activity" has become increasingly common in the psychological and pedagogical literature.

The innovative extracurricular activities in the field of educational management are considered by the authors as the implementation of innovations, pedagogical initiatives, modern technologies, ensuring the school management effectiveness. It is our belief that the readiness of a pre-service teacher as an education manager for innovative extracurricular work is a personal and professional quality characterised by the awareness of the importance and interests in extracurricular work on innovative grounds, the presence of satisfaction and motivation coupled with the simultaneous acquisition of special knowledge and skills embodied in the organization and management of extracurricular work; the needs of creative self-realization on a competent basis.

According to Ukrainian higher education reforms, the scope of tasks for educational establishments has expanded dramatically and has become much more complex (Serdiuk, 2018). Regarding schools, it is the unity of new and difficult tasks which has increased the role of a school teacher as a pedagogical manager. Because schools cannot afford to remain detached from the fast-moving changes that are taking place, they have made innovation one of their main priorities (Hepp et al., 2015). In our opinion, the teacher's management of educational and extracurricular activities of pupils generally refers to prognosis, planning, organizing, control, analysis and correction. It is possible to perform all these management functions efficiently if a teacher is competent in this. We consider that modernization of education requires the teacher's greater understanding of the specifics of the teacher's management activity content, including a number of personal qualities, managerial skills and professional competencies which are common for a teacher as a manager of their own and their pupils' activities with a view to continuous self-improvement and a high-level satisfaction and motivation. 
Pejić-Papak and Vidulin-Orbanić (2011) stressed that teacher's enthusiasm is not sufficient for good educational work and management of extracurricular activities, as teachers also need to be qualified for this work - professional knowledge and methodical preparation are necessary. We fully agree with this idea and would like to add that training such a highly qualified manager and teacher for future professional activity is not an easy task for pedagogical institutions, and it's only possible if we could implement the educational innovations in a timely and effective manner, giving extracurricular activity same importance as to the educational one. Pejić-Papak and Vidulin-Orbanić (2011) emphasised the equal importance of both education and extracurricular activities in educating a personality. In other words, in the current socioeconomic, political climate of Ukraine, our opinion is that the activity of the whole University in general, and of a teaching staff in particular regarding its extracurricular work with pre-service teachers is very important and undervalued at this point in time.

In the context of the research, two important facts should be also mentioned:

1) at most Ukrainian universities the pre-service foreign languages teachers' training for school extracurricular work is mostly held within the course of Pedagogy theory, which is taught in Ukrainian by educators who do not speak a foreign language on a sufficient level. This creates some difficulties in teaching students majoring in foreign languages and culture to conduct basic educational activities, organise holidays, celebrations as part of future extracurricular work in the foreign language classroom.

2) a pre-service teacher (excluding foreign philology department) mostly has only one foreign language lesson per week, sometimes as an optional course, and doesn't use this language at the extracurricular activity at a higher educational establishment. As a results, it is hard for students to improve their foreign language communicative skills at university with the aim of personal and professional development, meeting high European standards. This idea is also supported by the fact that an extracurricular approach to learning English is more effective because of the ability to provide a comfortable environment of support and collaboration (Alhasov et al., 2020, p. 18). The solution is using foreign languages and all the possible innovations in extracurricular activities at university, which creates the backgroung for this research.

Shapran and Shapran (2010) stated that innovative processes in higher education require the creation of an innovative educational environment aimed at implementing the strategic goals and objectives of educational development. The authors proposed the structure of an innovative educational environment which consists of three interrelated components (resource, logistical and technological), which determine the pedagogical conditions for its formation (p. 110). In the face of reduced classroom hours, extracurricular work with students is becoming increasingly important (Sandal et al., 2020, p. 26).

Tazhbayeva (2015) designed the structural and substantive model of the educational process in extracurricular activities, there were used both traditional forms of organization of extracurricular activities of students (curator hours, evenings, holidays, contests, etc.), and interactive (debates, workshops, business games, educational centres, clubs, etc.), but the innovative pedagogical technologies, methods and techniques, which could be effective and useful for our research were not defined by the author. Sandal et al. (2020, p. 24) divided all extracurricular activity into two groups, regarding their influence on the formation of components of foreign language communicative competence (linguistic and socio-cultural), but also didn't define the innovative component.

The innovations in education can improve learning outcomes and the quality of education provision, help enhance equity in the access to and use of education, as well as equality in learning outcomes. We agree that "there is a very strong correlation between education and skills and the uptake and use of digital technologies in various spheres of life" (OECD, 2016, p. 5). We agree with the statement but stress the importance of correlation between innovations and extracurricular technologies.

According to Marsh and Kleitman (2002) participation in co-curricular activities can improve learner's identification, involvement and commitment with their school in a way that leads to improved academic outcomes as well as non-academic outcomes. So, there is a direct connection between extracurricular activities participation and learners' outcomes. We agree that "extracurricular activity is any out-of-class involvement that absorbs students' energy, time, and attention" (Marsh and Kleitman, 2002, p. 465).

George $(2012$, p.86) proved that that participation in extracurricular activities has a statistically significant and positive relationship with academic achievement (socioeconomic status, educational attainment, and school influence). But the research was performed with the limiting of extracurricular activities to only four categories (arts, service clubs, interest clubs, and sports) and examined neither the impact of the number of participating in activities on student achievement, nor of innovations in it. The research by Shulruf et al. (2008) presented the methodology for effective measuring causal effects of a range of school-based interventions and activities on student achievements and attitudes. The benefit of the research by Buckley and Lee (2021) is that they proved that extracurricular work is crucial to students' 
success in higher education and defined the wide range of additionalities to the students' extra-curricular experience.

Massoni (2011, p.84) also defined the positive extracurricular effects on students (improving behaviour, school completion, better grades, positive aspects to become successful adults, and a social aspect). We completely agree with the author that teachers "need to be aware of the effects that extracurricular activities have on school education" (86), but the paper didn't contain the aspect of monitoring its effectiveness, along with the students' attitude towards these activities at school and possible negative effects etc. In Wilson's (2009, p. 25) opinion, the positive benefits outweigh the negative: spending less time studying; the parents' forcing a child to be involved in too many activities according to their choice, or just too many activities; the participating in sports may illicit the use of drug or alcohol; the unfair advantage for those of a higher economic status; the limit of family finances (for additional training, top-notch equipment etc.); sports injuries etc.

The problem of the pre-service teachers' training for the innovative extracurricular work at school, especially on the example of pre-service foreign languages teachers' training at university, has not been the subject of special research yet. We agree that nowadays the main measure of the quality of the higher education system should be the ability of the younger generation to live fully and actively in the new world, constantly improve, respond adequately to change, especially in periods of technological and civilizational breakthroughs, globalization and integration processes (Solovey and Demchuk, 2017).

The specially designed programme of pre-service teachers' training to innovative extracurricular work is believed to increase the students' level of readiness for innovative extracurricular work at school and of their satisfaction with it at University. It'll meet the modern school needs, having trained pre-service teachers as creative educational managers and developed their individual qualities, professional knowledge and skills (organizational, managerial and communicative including), and improve pre-service teachers' training by modernizing the extracurricular work at University, having implemented innovations and foreign languages in it. With consideration to the points above, we believe our research to be relevant and timely.

This research aim to ground the effectiveness of the holistic programme of pre-service teachers' training to innovative extracurricular work, which increases the students' level of readiness for innovative extracurricular work at school and of their satisfaction with it at university, and to substantiate the methodical recommendations to such training realisation.

\section{Methods}

\section{Research design}

The study employed the mixed-method research design as combining both qualitative and quantitative approaches. The quantitative research method was used to assess the general index of pre-service teachers' satisfaction with the extracurricular work using the Shkvyr's formula and the effectiveness of the developed holistic programme using the Pearson's coefficient. The qualitative research method allowed us to analyse and interpret the data of the experiment. This method was also employed to evaluate the students' self-esteem of their readiness to the extracurricular work, the level of the pre-service teachers' readiness for innovative educational work.

The participants of the pedagogical experiment were 148 second-year and third-year students of the Philological Faculty of the Hryhorii Skovoroda University in Pereiaslav (the age ranged from 18 to 21 years, all they were Ukrainians and were of both sexes), all of them are pre-service foreign languages teachers (of English and German/French languages). During the pedagogical experiment, 10 teachers of Pereiaslav General Secondary Schools № 2, № 3, № 7 and 18 teachers of the University took part as experts (Pereiaslav, Kyiv region, Ukraine). The total number of participants was 176. The students were placed into two groups: 74 in an experimental group (hereinafter: EG), studied under experimental pedagogical conditions, and 74 in a control one (CG) under traditional programmes.

It should be noted that the extracurricular work of the Hryhorii Skovoroda University in Pereiaslav is always planned beforehand and carried out in different areas (cultural and educational activities, patriotic upbringing, legal upbringing, sports and health care work, creative and information work, volunteering, scientific work etc.). Participation in all traditional extracurricular activities is equally accessible to students of all faculties. Relying on the fact that many philological faculty students have been taking part in extracurricular activities at the university, we should note that the EG and CG have had equal possibilities for participating in university-wide and faculty-wide extracurricular work, but additionally the experimental programme has been designed and realised only for the EG students. 


\section{Procedure and data collection tools}

During the research process we developed a holistic programme of pre-service teachers' training to innovative extracurricular work at the Hryhorii Skovoroda University in Pereiaslav, the structure of which consisted of three consecutive interconnected stages: organizational (September, 2018), content (SeptemberNovember, 2018), and formative (November, 2018-July, 2020). The procedure of the first and third stages of the research provided three steps: 1) the questionnaire for students with the aim of identifying the general index of their satisfaction with the extracurricular work; 2) a students' self-assessment of their readiness for innovative extracurricular work; 3 ) the questionnaire for experts about the students' readiness for innovative extracurricular activity as a teacher at school. The organizational stage was considered by us as the preexperimental stage of the programme, the experimental part of the programme was realised at the content stage and the first part of the formative stage. The results of the experiment were obtained and analysed at the end of the formative stage as a post-experimental part.

The holistic programme of pre-service teachers' training to innovative extracurricular work was realised under certain conditions which had been divided into three groups: organizational and pedagogical conditions (the unity of education and innovative extracurricular activities, the fusion of Ukrainian traditions and international experience; improving the methodical component of professional training of pre-service teachers; strengthening the links between higher and secondary schools in the process of practice; increasing the duration of the practice for training pre-service teachers), philological conditions (providing the implementation of foreign languages into extracurricular work; constant developing and improving the preservice teachers' communicative skills), psychological and pedagogical conditions (actualization of the students' value and motivational sphere to develop innovations, to succeed and be satisfied in future educational activities; providing integrated practice-oriented and extracurricular content of the pre-service teachers' training process; developing reflective awareness of their readiness for future innovative extracurricular work; the approximation of professional training of pre-service teachers to the real conditions of future pedagogical activities; psychological and pedagogical support).

Important instructions were given to participants: to participate in all or the majority of experimental extracurricular activities and be focused on this kind of work, to try to be active and creative, to be tolerant and accurate to children (during practice) and other participants of the experiment. All the participants were informed that they could stop participation at any time.

The organizational stage of our research was carried out in order to identify the general index of preservice teachers' satisfaction with the extracurricular work, their self-esteem of the readiness for innovative extracurricular work and the experts' evaluation of it. The authors' questionnaires "Students' self-esteem of their readiness to the extracurricular work in future" contained 20 questions, where the key questions were about the level of students' satisfaction with university extracurricular work and their readiness to the future extracurricular work at school, the other questions were about their own experience of practical innovative extracurricular activity, the factors influencing their readiness to it, the impact of particular forms on the formation of pre-service teachers' creative style of extracurricular work at school, on their individual qualities, general professional knowledge and skills, also about the importance, attractiveness and novelty of specific extracurricular forms, the importance of innovations and foreign languages implementing into extracurricular work, the conditions for increasing the productivity of the university extracurricular work and its perspectives etc.

The students of both groups were proposed to answer the question "Are you satisfied with the extracurricular work at the Philological Faculty of the University?" grading: "Very satisfied"; "Satisfied"; "Mostly satisfied, than dissatisfied"; "Indifferent"; "Mostly dissatisfied, than Satisfied"; "Not satisfied at all"; "Uncertain position", choosing one from these 7 probable answers. Based on the analysis of the answers, a general satisfaction index was determined according to the Shkvyr's formula (Shkvyr, 2018, p. 274):

$$
I=\frac{a(+1)+b(+0,5)+c(-0,5)+d(-1)+e(0)}{N}
$$

There were such elements in the given formula: "I" was a satisfaction index; "N" was the number of respondents; "a" - the number of very satisfied students; "b" - the number of students mostly satisfied, than dissatisfied; "c" - the number of students who are indifferent; "d" - the number of students mostly dissatisfied, than satisfied; "e" - the number of students not satisfied at all; "f" - the number of students with uncertain position.

The results of that stage (as well as after the experiment) of the programme implementation can be seen in Table 1, Figure 1. 
The content stage of the experimental programme presupposed the implementation of new theory (basic notions and aspects of innovative extracurricular work) into the system of disciplines for EG group, namely: "General Pedagogy", "History of Pedagogy", "Fundamentals of Teachers' Pedagogical Skills", "Methods of Extracurricular Work" etc. The goals, objectives and programmes of these courses were changed; the content of disciplines was expanded with new knowledge about innovative extracurricular methods and forms.

At the content and formative stages of the experiment, the programme also presupposed the minilectures on pre-service teachers' training to innovative extracurricular work, using various techniques (audiovisual presentations, like slides, videos, drawings, models, diagrams, tables), including pre-prepared student speeches, questions according to the topic of the lecture; structural and logical technologies (pictorial supports, substitution tables); online programs (Google Earth, Puzzle Makers, Word Search Makers, Dice Makers, Bingo Cards Makers, Board Game Makers, Crossword Magic, Frame Teach); editors (graphics, sound, video); screen recording programs (Photoshop, Movie Maker); didactic materials with the use of shell programs (Hot Potatoes, My Test).

The formative stage of the implementation of the holistic programme of pre-service teachers' training to innovative extracurricular work was characterised by the usage of such innovative methods and forms of extracurricular work at university as:

- press-conferences ("Features of the implementation of innovative extracurricular activities", "Methods of organizing extracurricular work with the use of innovative technologies", "Modern gadgets usage for upbringing purposes", "Internet VS Real Communication", "How to become a leader?", "Leader: Like/Dislike", "Internet for Upbringing Purposes") (which were held in English),

- extracurricular projects ("Intercultural Communication", "What should a foreigner know about Ukraine?", "Ukraine is an independent state", "Episode on the history of Ukraine", "Welcome to Ukraine", "Cultural Life of Youth", "Youth struggle for peace", "How can a university make the students' life more interesting", "Is it possible and useful to be an ideal .... (parent/ teacher/student/person)" etc.) (in English);

- the system of trainings (partner communication training, creativity training "Express Yourself", psychological trainings like "Leadership", "Rare Bird: For and Against?", "Empathy", "Share Positive Emotions", "Joy for me", "Message Corner", sensitivity training, etc.), some of them had the variable topic, which could be chosen by the EG students themselves at the beginning of it or beforehand ("Let's talk about...", "Poster about ... (happiness/love)", etc.) (in English);

- game technologies ("Initials", "Continue the chain") (in English);

- upbringing games ("Realist, Dreamer and Sceptic", "Actors", "Kaleidoscope", "Climber", "Merry Polyglot", "Auction of Letters", "Treasure Chest", "Stand-up Comedy", "Lucky Chance", "Brain Ring") (in English);

- business and role-playing games, game educational situations ("Once at school ...", "Teacher-parent Meeting", "Class Trip", "Naughty Children", "Headmaster and Young Teacher", "Educational Exhibition", "Talk Show", including game discussions and solving professional problems, exercise games (puzzles, quizzes), games-competitions between student teams etc.) (in English, some of them in German, French);

- quests (real travel quests, imaginary travelling quests, virtual quests "Google Earth Traveller", "Virtual Trip of my Real Dream") (in English, some of them in German, French);

- excursions to the museums and prominent places of the town (in English, German, French);

- online meetings with interesting and popular people of Ukraine and Kyiv region (poets, writers, journalists, teachers) (in Ukrainian);

- competition "The Best Dormitory Room of the Faculty" (once a year in winter) (in Ukrainian);

- outdoor cinema (original movies "Front of the Class", "Freedom Writers", "The Ron Clark Story" etc.) (in English);

- "night football" (a football match between the two teams of students living in dormitories (№1 and №2), which is held late at the weekend evening, usually in June, and supported by the University teachers as referees and students as fans; a match could be played either by non mixed teams (only one gender students) or mixed teams (with a minimum of two female players in a team)) (in Ukrainian);

- complex forms of educational work with student youth (Open Day (twice a year), Profession Day, Music Sunday etc.) (in Ukrainian).

These methods and forms were realised with the assistance and support of the dean's office of philological faculty, student assets of Hryhorii Skovoroda University in Pereiaslav.

In order to improve the pre-service teachers' training for innovative extracurricular work at school, the programmes of pedagogical practice for pre-service foreign language teachers were also upgraded with credits extension (from 21 to 25.5), experimental applications and creativity tasks (f.ex. to produce plans for 
two innovative extracurricular activities (for the $3^{\text {rd }}$ year students, 2019-2020), to organise and hold three such activities (for the $4^{\text {th }}$ year students, 2019-2020) etc.). There were four pedagogical practices every year.

During the experiment, a toolkit of diagnostic techniques was used, which corresponded to the structure of the studied quality, namely: "Methods of studying the personality motivational profile (Richie and Martin, 2004, p. 7-12), "Diagnosis of self-development needs "(Fetiskin, Kozlov and Manuilov, 2002, p. 47-48); "Diagnosis of the formation of pedagogical reflection" (Kalashnikova, 1998, p. 22-26); the modified version of Mednik's test "Your creative potential" (as cited inTurynina, 2007, p. 116-119), method "Assessment of students' creative potential at pedagogical establishment of higher educational" (Andrieiev, 2012, p. 550551), author's questionnaires "Students' self-esteem of their readiness to the extracurricular work in future", "Innovations in education" (the students' knowledge on innovations in education, extracurricular including), questionnaire for experts "Student's readiness for innovative extracurricular work".

Validity and reliability of the research data were proved by the fact of alignment of the pedagogical experiment results, on the basis of respondents' questionnaire and self-evaluation, pedagogical observation, experts' (University and school teachers) questionnaire, comparing with the results of the control group beyond the experiment.

Ethical principles of the research. All the respondents and experts participated in the experimental research on their own free will. The designed programme was realised with the respect to human rights and ethical principles.

\section{Results}

We'd like to remind that the hypothesis of the research is that level of pre-service teachers readiness for innovative extracurricular work at school will be increased together with the general index of their satisfaction with the extracurricular work at university after the implementation of the designed holistic programme of their training.

In order for our results to be meaningful, at the very beginning the students were divided into two groups grounding onto the principle of equality to be comparable. So, the number of the participants were equal in both groups, which were of the same race, both genders, having the same average age (19 years old), and above EG and CG have a similar state of their readiness to the future extracurricular work at school and the index of their satisfaction with the extracurricular work at University.

The experimental research showed the following results.

1. Calculating the received data, the general index of the students' satisfaction with the extracurricular work at the university on the basis of the questionnaire was identified as a growing one.

At the beginning of the experiment, the general satisfaction index of the respondents of both groups (EG and CG) were almost the same $(0,47$ and 0,48$)$, which means that the division of students into these two groups was done correctly (Table 1$)$.

Table 1. General index of the respondents' satisfaction with the extracurricular work (organizational stage)

\begin{tabular}{|c|c|c|c|c|c|c|c|}
\hline \multirow[t]{2}{*}{ Group } & \multicolumn{6}{|c|}{ Quantity of respondents } & \multirow[t]{2}{*}{ General index } \\
\hline & General & $a$ & $b$ & $c+f$ & $d$ & $e$ & \\
\hline EG & 74 & 22 & 40 & 6 & 5 & $\overline{1}$ & 0,47 \\
\hline CG & 74 & 20 & 44 & 4 & 4 & 2 & 0,48 \\
\hline
\end{tabular}

We should note that the number of very satisfied students of EG is $29,7 \%$, of CG $-27 \%$, the number of students mostly satisfied, than dissatisfied is 54\% in EG, 59\% in CG, the number of students who are indifferent and with uncertain position is $8,1 \%$ of EG students and 5,4\% of CG students (the general percentage of both groups is $6,7 \%$ ), the number of students mostly dissatisfied, than satisfied is $6,7 \%$ of EG students and 5,4\% of CG students, almost equal number of the students (1,4\% of EG and 2,7\% of CG) aren't satisfied with the extracurricular work. So, the general percentage of both group students' self-esteem in their indifference and dissatisfaction (17,5\% for EG and 13,5\% for CG) gives the thought that the reason of this is that these students aren't involved and interested in the extracurricular activity, not motivated for it properly, and, consequently, their incompetency in it. Such data enhanced the research theme's actuality.

The formative stage of the pedagogical experiment showed the increase of the general index of the EG students' satisfaction with the extracurricular work at the University, but the satisfaction with it by the CG students remained almost the same as before the experiment (Table 2). 
Table 2. General index of the respondents' satisfaction with the extracurricular work (post-experimental stage)

\begin{tabular}{|c|c|c|c|c|c|c|c|}
\hline \multirow{2}{*}{ Group } & \multicolumn{6}{|c|}{ Quantity of respondents } & \multirow{2}{*}{ General index } \\
\cline { 2 - 7 } & General & $a$ & $b$ & $c+f$ & $d$ & $e$ & \\
\hline EG & 74 & 40 & 31 & 3 & 0 & 0 & 0,73 \\
\hline CG & 74 & 19 & 43 & 11 & 2 & 0 & 0,47 \\
\hline
\end{tabular}

The general satisfaction index of the respondents of the EG increased to 0,73 , but the index of CG remained the same as before the experiment, even lower $(0,47)$. The increase of the EG satisfaction index proved that the experimental programme had been successfully conducted.

2. The students' self-assessment of their readiness for innovative extracurricular work showed also the significant increase. We distinguished such levels of their readiness as: innovative, productive, receptive, reproductive. The organizational (pre-experimental) stage of our research presupposed the questionnaire assessing the students' self-esteem regarding their readiness for innovative extracurricular work. The results showed that: 1) $4 \mathrm{EG}$ respondents $(5,4 \%)$ were ready at the innovation (high) level, 20 students were ready at the productive level (middle level) (27\%), 31 students were ready at the reproductive level (41,9\%), 19 $(25,7 \%)$ were not; 2$) 4 \mathrm{CG}$ respondents $(5,4 \%)$ were ready at the innovation (high) level, 21 students were ready at the productive level (middle level) $(28,4 \%), 30$ students were ready at the reproductive level $(40,5 \%), 19(25,7 \%)$ were not (Figure 1).
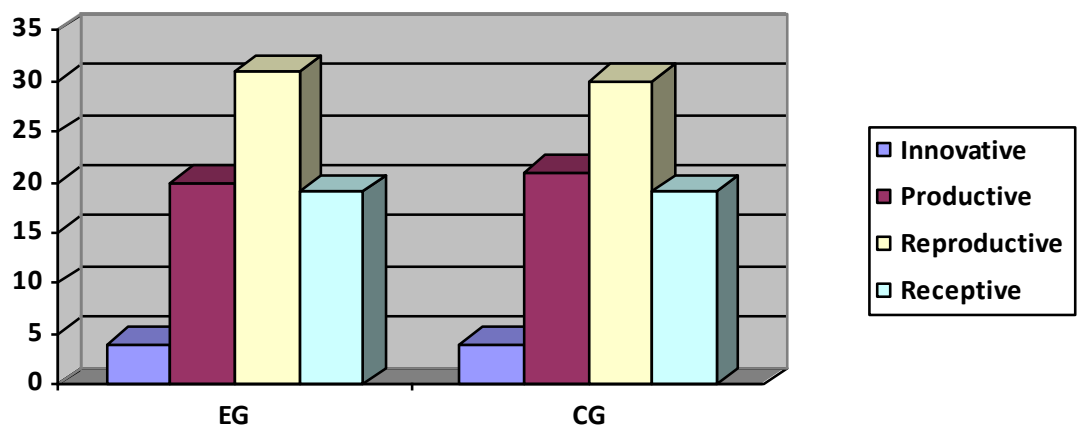

Figure 1. Students' self-esteem of their readiness to the extracurricular work before the experiment

After the experiment (post-experimental stage) there was a great increase in the EG data in the diagram, which is confirmed by the fact that 18 EG respondents $(24,3 \%)$ were ready at the innovation (high) level, 45 students were ready at the productive level (middle level) $(60,8 \%), 11$ students were ready at the reproductive level (14,9\%), 0\% were not. The results of the CG student answers confirmed that 7 EG respondents $(9,5 \%)$ were ready at the innovation (high) level, 25 students were ready at the productive level (middle level) $(33,8 \%), 26$ students were ready at the reproductive level $(35,1 \%), 16(21,6 \%)$ people were not ready at all (Figure 2).

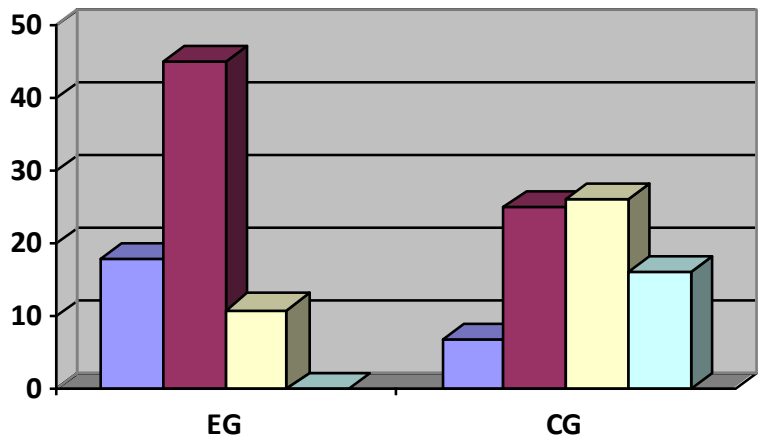

\begin{tabular}{|l|}
$\square$ Innovative \\
$\square$ Productive \\
$\square$ Reproductive \\
$\square$ Receptive
\end{tabular}

Figure 2. Students' self-esteem of their readiness to the extracurricular work after the experiment

The data showed that the students' self-assessment of their readiness for innovative extracurricular work had increased significantly after the experimental programme (the innovative level of EG increased from $5,4 \%$ to $24,3 \%$, comparing with CG - from $5,4 \%$ to $9,5 \%$; the productive level of EG increased from $27 \%$ to 
$60,8 \%$, compared to CG - from $28,4 \%$ to $33,8 \%$ ). So, this increase in the students' self-esteem in average was 3 times as much.

Despite the fact that most respondents identified themselves as ready people for innovative extracurricular work at innovative and productive levels (EG-85\%, CG-42\%), we put forward an idea that when answering this question before the experiment some of the students deflated self-esteem and it wasn't really true to life then, probably it could be also the same after the experiment.

That's why we placed emphasis on interviewing the experts (university and school teachers of the respondents) on finding their opinion on the level of students' readiness for an innovative extracurricular work at school; they were proposed to interview and observe students, and asked to grade them in a questionnaire according to the appropriate levels of their readiness for innovative extracurricular work. The implementation of a holistic programme of pre-service teachers' training to innovative extracurricular work provided an opportunity to experimentally test their effectiveness at the level of comparing the results of the statement and formative sections of the experiment. The teachers of Pereiaslav General Secondary Schools № 2, № 3, № 7 helped us to prove the dynamics of the students' level of readiness, which they could meet and work with them during academic practices at school.

Comparing the data of students' self-esteem and experts' evaluation, we defined the reduced results of the students' results, probably, because of their fear not to cope with innovation at school, and higher results of the teachers' answers, which we consider more relevant because of their professional experience and wisdom.

3. The experts' observation and evaluation of the dynamics of the levels of pre-service teachers' readiness for innovative extracurricular work was identified as much increased for EG students and less increased (almost stable) for CG (Table 3).

Table 3. Dynamics of the levels of pre-service teachers' readiness for innovative extracurricular work (the experts' evaluation)

\begin{tabular}{|l|c|c|c|c|c|c|c|c|}
\hline \multirow{4}{*}{ Levels of readiness } & \multicolumn{4}{|c|}{ EG } & \multicolumn{4}{c|}{ CG } \\
\cline { 2 - 10 } & $\begin{array}{c}\text { Number of } \\
\text { respondents }\end{array}$ & \multicolumn{2}{|c|}{$\%$} & \multicolumn{2}{c|}{$\begin{array}{c}\text { Number of } \\
\text { respondents }\end{array}$} & \multicolumn{2}{c|}{$\%$} \\
\cline { 2 - 10 } & Before & After & Before & After & Before & After & Before & After \\
\hline Innovative & 6 & 19 & 8,1 & 25,7 & 6 & 7 & 8,1 & 9,5 \\
\hline Productive & 21 & 46 & 28,4 & 62,2 & 22 & 26 & 29,7 & 35,1 \\
\hline Reproductive & 29 & 9 & 39,2 & 12,2 & 29 & 24 & 39,2 & 32,4 \\
\hline Receptive & 18 & 0 & 24,3 & 0 & 17 & 17 & 23 & 23 \\
\hline
\end{tabular}

The statistics obtained after the formative experiment proved that it was a positive dynamics of the levels of readiness of pre-service teachers for innovative educational work in the EG, namely: the innovative level increased by $17,6 \%$, the productive level of readiness increased by $33,8 \%$, and the reproductive level decreased by $27 \%$, the receptive level of readiness decreased from $24,3 \%$ to $0.0 \%$.

During the same period, the CG showed the following results: the number of students with an innovative level increased by $1,4 \%$ and reproductive level of readiness increased by $5,4 \%$, the productive level of readiness decreased by $6,8 \%$, the receptive level of readiness didn't change.

The comparison of the research results of the conducted pedagogical experiment allowed us to conclude the significant differences in the readiness of pre-service teachers of the EG in relation to the CG. The results proved that there was a significant positive dynamics of the formation of all components of the pre-service teachers' readiness for innovative educational work in the experimental group of respondents.

In order to show the correlation of the used diagnostic techniques with the results of the experiment in detail, we've systematised the achieved results according to the particular component of the pre-service teachers' readiness for innovative educational work, its criteria, which were tested before and after the experiment by the particular technique (Table 4). The levels of the criteria are marked by the letters: " $\mathrm{H}$ " for high level, which refers to the innovative level of the readiness ("I"), "M" for middle level, which is the productive level of the readiness ("P"), "S" for satisfactory level, that refers to the reproductive level of the readiness ("Rp"), "L" for low level, that refers to the receptive level of the readiness ("Rc"). 
Table 4. Correlation of used diagnostic techniques with the achieved results according to the components of the pre-service teachers' readiness for innovative extracurricular work, its criteria, groups and levels

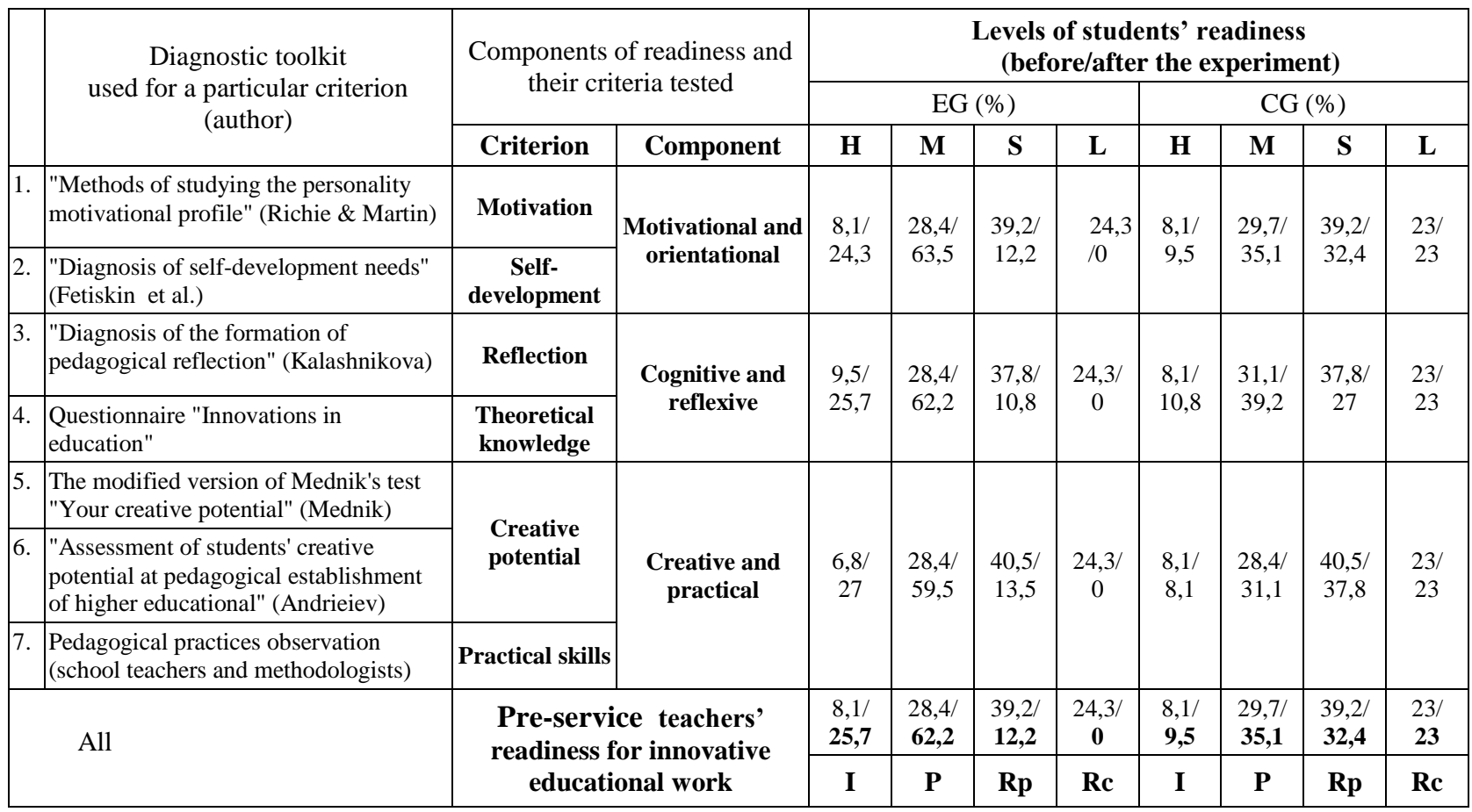

The effectiveness of the developed holistic programme of training pre-service teachers to innovative extracurricular work at school wasn't only proved by experts and students, but also by the methods of mathematical statistics - $X^{2}$-criterion (the Pearson's coefficient) for the significance level of 0,01 , where the value of $X^{2}$ was greater than $X^{2}$ cr $(20,32>11,32)$, which proved the effectiveness of the experimental programme.

The experiment showed that the pre-service foreign languages teachers at EG were most impressed by the following forms of innovative extracurricular work: imaginary and virtual quests, debates, games (Standup Comedy, "Lucky Chance", "Brain Ring"), "pillow fights", outdoor cinema, "night football", online meetings with popular persons. Such forms were considered to be really innovative for them.

\section{Discussion}

The present research proved existing links between increasing the level of students' readiness for future innovative extracurricular work at school and the general index of their satisfaction with it during their studies at university; between participating in innovative extracurricular activities and developing their individual qualities (motivation, pedagogical reflection, creativity potential, self-development etc.), professional knowledge and practical skills (organizational, managerial, communicative etc.); between the creative atmosphere of higher education institution's innovative extracurricular work and the students' desire to perform future pedagogical activity creatively.

The results of the experiment convinced that extracurricular work is a necessary component of the general process of forming a modern competent teacher's personality, which leads to personal and professional development (developing individual qualities, improving professional knowledge and skills, providing spiritual wealth and a high culture of feelings, confidence and creativity in future professional activities, maximum satisfaction of cognitive and cultural needs etc.). This study found statistical significance and positive change between participation in extracurricular activities in University, students' satisfaction with it and their readiness for innovative extracurricular work at school.

The results obtained by us are also in agreement with the study of Moran (2017) on the impact of extracurricular activity on teacher job satisfaction, but we concluded that involvement in extracurricular activities is a positive thing not only for students and teachers but also could be useful for the development of higher and secondary education institutions. We agree with the statement that "teacher professional activity satisfaction is extremely important and should not be overlooked" (Moran, 2017, p.83), and that there is not only the impact of school extracurricular activity on teacher job satisfaction but the impact of the satisfaction with University extracurricular activity on the pre-service teacher's readiness for innovative extracurricular work at school afterwards. 
Taking into account the fact that all the pre-service education managers, teachers, should have greater autonomy in providing education, that is more suited to meet the needs of learners, but should also be monitored externally to ensure its relevance to a certain level, it is very important that an effective training programme for pre-service teachers, as the designed one, could be developed and implemented into every pedagogical institution of higher education in Ukraine. Such a programme can be effective with the focus on the unity of education and innovative extracurricular activities, of Ukrainian traditions and international experience and assistance as important resources to solve these problems and coordinate the efforts of all participants in the educational policy process. With a view to broadening the perspective of the research, we developed the recommendations for improving the pre-service teachers' training for innovative extracurricular work, taking into account our results and the previous research (Hepp et al., 2015; Marsh, 2002; Pejić-Papak and Vidulin-Orbanić, 2011; Tazhbayeva, 2015; Sandal et al., 2020; Solovey and Demchuk, 2017; Shapran and Shapran, 2010; Shulruf et al., 2008; Wang and Yang, 2009 etc.). Among the recommendations for training pre-service teachers, we consider it important that the all areas of training (theoretical, methodological, practical) should be interrelated to each other, using potential of every study course, especially of psychological and pedagogical character, as well as of pedagogical practice. It is appropriate to follow interactive, integrative and problem-based approaches during the development and implementation of such a programme. Creating an innovative educational environment, transforming traditional forms and methods of extracurricular work into practice-oriented and innovative (f.ex. a simple tour could become a virtual one with the help of Google Earth, etc.), using all possible platforms, technologies, tools and methods (as offered in the developed holistic programme), will help to increase the readiness of pre-service teachers to innovative extracurricular work at school. Ensuring the integrity of the innovative extracurricular activity with a focus on the student's personality and achievements, creating conditions for their self-realization and meeting their professional needs are very important. It's necessary to monitor students' satisfaction, which can help judge which extracurricular methods and forms are of students' great interest to enable them to develop their knowledge and skills needed to become a successful teacher.

We believe that university extracurricular activities in a foreign language, where a student feels freer, more comfortable, confident and calm, can be as valuable as language classes in the context of overcoming language barriers, developing foreign language communication competence, together with practical skills, individual qualities and readiness for future activities at school. The inclusion of students in active reflexive dialogue is considered to be appropriate (including reflecting through interviewing, testing, monitoring the students' likes and reposts of articles at university/faculty network pages, writing articles or reviews, etc.).

Limitations. Although the focus of the article was on highlighting, analysing and interpreting the results of the experimental testing of the designed holistic programme of pre-service teachers' training to innovative extracurricular work, it does not provide a more comprehensive picture of the process. Firstly, the study was limited by participation only of second-year and third-year students of the same speciality and specialization. So, a similar programme can be carried out in related specialities and specializations, in other subject domains at other faculties. Secondly, the study was also limited by reluctant online form because of the pandemic COVID-19 (March, 2020 - July, 2020), and it would be advisable to use some innovative methods and forms, which we couldn't have used (trips to different Ukrainian cities and European countries with students and schoolchildren, visiting theatres and museums abroad, the students' work with pupils beyond the classroom etc.).

\section{Conclusions}

The analysis of the study shows the effectiveness of the designed holistic programme of pre-service teachers' training for innovative extracurricular work which increases their readiness for such activities at school and satisfaction with it at the university. The idea to train teachers as competent and highly qualified professionals, capable of carrying out not only educational but also innovative extracurricular activities, using modern pedagogical technologies, methods and techniques, is followed. The authors also consider the programme important because it provides a favourable innovative environment (press conferences, extracurricular projects, trainings, various games, quests (real, imaginary, virtual), outdoor cinema, "night football", online meetings with popular persons etc.). This space helps students to try and test the obtained skills and abilities of extracurricular work, to master the basics of pedagogical innovations, to develop their innovation resources and to realise the innovative extracurricular potential of the University in general. The last corresponds to the decisive factor in the economic and educational development of Ukraine which is the university education quality in the direction of training professionals adapted to rapid changes in society and 
focused on improving their professional readiness for curricular and extracurricular activities. The programme improves the University extracurricular activities quality which is determined by the achievement of educational goals and objectives, the dynamics of students' personal development, social activity and readiness for innovative extracurricular activities at school with modern innovative pedagogical technologies introduction.

It should be added that the readiness of pre-service teachers for innovative extracurricular activities is the basis for their innovative and educational competence, that is an integrated personal quality of teachers, which is manifested in readiness to perform innovative extracurricular work from a hypothesis to the innovation implementation on the ground of the system of motives, knowledge, skills, professional and personal qualities, extracurricular work experience.

The prospects of further research are theoretical grounding and practical implementation of the programme of the pre-service foreign languages teachers' readiness for innovative extracurricular activities for children with special needs. Further research may be also devoted to the research on specifities of innovative extracurricular in distance format and the problems of motivating students to participate in extracurricular activities.

\section{References:}

Alhasov, Y., Verbytska, A., \& Kolenichenko, T. (2020). Teaching English to adult learners within extracurricular activities at university: barriers and motivation factors. Advanced Education, 7(15), 12-19. https://doi.org/10.20535/2410-8286.195696

Andrieiev, V. (2012). Pedahohyka: Uchebnyy kurs dlia tvorcheskoho samorazvytyia [Pedagogics: Study course for creative selfdevelopment]. Kazan, Russian federation: Centre of innovational technologies. Retrieved 11 August 2021 from https://logos-press.ru/docs/pedagogika.pdf

Buckley, P., Lee, P. (2021). The impact of extra-curricular activity on the student experience. Active Learning in Higher Education. 22(1),37-48. https://doi.org/10.1177/1469787418808988

Fetyskyn, N., Kozlov, V., \& Manuilov, H. (2002) Sotsyalno-psykholohycheskaia dyahnostyka razvytyia lychnosty y malykh hrupp [Social and psychological diagnostics of the development of personality and small groups]. Moscow, Russian federation: Publishing house of the Institute of Psychotherapy. Retrieved 11 August 2021 from https://www.phantastike.com/psychodiagnostic_systems/s_p_diagnosis/pdf/

George, S. (2012). A Study of the Relationships Between Extracurricular Participation in Selected North Carolina High. PhD thesis, Appalachian State University, Boone, North Carolina, United States. https://edl.appstate.edu/sites/edl.appstate.edu/files/sandy_georgefinal_paper.pdf

Hepp K., P., Prats Fernández, M. À, \& Holgado García, J. (2015). Teacher training: technology helping to develop an innovative and reflective professional profile. RUSC. Universities and Knowledge Society Journal, 12(2), 30-43. http://dx.doi.org/10.7238/rusc.v12i2.2458

Marsh, H., \& Kleitman, S. (2002). Extracurricular School Activities: The Good, the Bad, and the Nonlinear. Harvard Educational Review, 72(4), 464-515. https://doi.org/10.17763/haer.72.4.051388703v7v7736

Massoni, E. (2011). Positive Effects of Extra Curricular Activities on Students. ESSAI, 9 (27), 85-87. https://core.ac.uk/download/pdf/10676858.pdf

Moran, J. P. (2017). The Impact of Extracurricular Activity on Teacher Job Satisfaction. PhD thesis, Youngstown State University, Youngstown, Ohio, United States. Retrieved 11 August 2021 from https://etd.ohiolink.edu/apexprod/rws_etd/send_file/send?accession=ysu1492182067273518\&disposition=inline

OECD (2016). Innovating Education and Educating for Innovation: The Power of Digital Technologies and Skills. Paris, France: OECD Publishing. http://dx.doi.org/10.1787/9789264265097-en

Onyshchenko, N. (2012). Innovatsiyni pedahohichni tekhnolohiyi v systemi profesiynoyi pidhotovky maybutnikh uchyteliv [Innovative pedagogical technologies in the system of future teachers' vocational training]. Bulletin of the Taras Shevchenko Luhansk National University, 22 (6), 36-44. Retrieved 11 August 2021 from http://nbuv.gov.ua/UJRN/vlup_2012_22(6)_7

Pejić-Papak, P. \& Vidulin-Orbanić, S. (2011). Stimulating active learning in extracurricular activities through contemporary work strategies. Metodički obzori, 6(2011)2 (12), 5-21. https://doi.org/10.32728/mo.06.2.2011.01

Ritchie, S., \& Martin, P. (2004). Upravlenye motyvatsyei: Ucheb. posobye dlia vuzov [Motivation management]. (Transl. and ed. E.A. Klymova). Moscow, Russian federation: Yuniti-Dana. Retrieved 11 August 2021 from https://hr.ikombat.ru/files/309/sh-richi-p-martin-upravle.pdf

Sandal, J.-U., Detsiuk, T., \& Kholiavko, N. (2020). Developing foreign language communicative competence of engineering students within university extracurricular activities. Advanced Education, 7(14), 19-28. https://doi.org/10.20535/2410-8286.192411

Serdiuk, N. (2018). Current state and problems of the development of the ukrainian higher education. Professional Education: Methodology, Theory and Technologies, 7, 188-204. Retrieved 11 August 2021 from https://educationjournal.org/index.php/journal/article/view/112

Shapran, O., Shapran, Yu. (2010). Creating an innovative educational environment in the process of preparing a future teacher. Pedagogy, psychology and methodical-biological problems of physical education and sports, 9, 108-110. Retrieved 11 August 2021 from https://www.sportpedagogy.org.ua/html/journal/2010-09/10soitpt.pdf

Shkvyr, O. L. (2018). Theoretical and Methodical Principles of Stage Preparation of the Future Primary School Teachers for Conducting Pedagogical Researches. PhD thesis, Zhytomyr Ivan Franko State University, Zhytomyr, Ukraine. Retrieved 11 August 2021 from http://eprints.zu.edu.ua/27035/1/dys_Shkvyr.pdf

Shulruf, B., Tumen, S., \& Tolley, H. (2008). Extracurricular activities in school, do they matter? Children and Youth Services Review, 30, 418-426. https://doi.org/10.1016/j.childyouth.2007.10.012 
Solovey, M., \& Demchuk, V. (2017). Orhanizatsiyni ta metodychni zasady vykhovnoyi diyal'nosti v Universyteti [Organizational and methodical fundamentals of educational activity at the university]. Theoretical questions of culture, education and upbringing, 1, 28-38. Retrieved 11 August 2021 from http://nbuv.gov.ua/UJRN/Tpkov_2017_1_9

Tazhbayeva, S.G. (2015). Scientific Basis of the Future Teachers Extracurricular Activities Organization (Educational Aspect). European Online Journal of Natural and Social Sciences, 4(4), 638-654. Retrieved 11 August 2021 from https://europeanscience.com/eojnss/article/view/2886

Turynina, O. L. (2007). Psykholohiia tvorchosti : Navch. posib. [Psychology of creativity]. Kyiv, Ukraine: International Academy of Personnel Management. Retrieved 11 August 2021 from https://studfile.net/preview/5045131/

Wang, J., \& Yang, W. (2009). The Extracurricular Scientific and Technological Activities of College Students and the Training of Innovative Spirits. In Xiaonan Xiao and Frank Bünning (Eds.), Proceedings of 2009 International Conference on Education Management and Engineering. https://doi.org/10.2991/seiem-16.2016.121

Wilson, N. (2009). Impact of Extracurricular Activities on Students. MS Research Paper. The Graduate School University of Wisconsin-Stout Menomonie, WI, United States. Retrieved 11 August 2021 from https://www2.uwstout.edu/content/lib/thesis/2009/2009wilsonn.pdf 